\title{
O FEMINISMO DE V!RGINIA WOLLF EM A ROOM OF ONE'S OWN
}

Sigrid Renaux

O fato de Virginia Woolf ser conhecida como uma das grandes inovadoras do romance inglês do século $X X$ e, juntamente com Joyce, ter desenvolvido a técnica do fluxo de consciência, fez com que a ensaísta ficasse um tanto negligenciada pela crítica, preocupada em explorar cada vez mais seus romances mais famosos, como To the Lighthouse, Orlando, Mrs. Dalloway! e Night and Day (já traduzidos para o português), entre outros. Realmente, a prosa não ficcional de Virginia Woolf é apenas citada sumariamente nos livros que tratam da ficção inglesa do século $X X$ e que salientam os aspectos vanguardistas de sua prosa.

Como especificamente aqui no Brasil A Room of One's Own ${ }^{1}$ aincia não está traduzido e em conseqüência é conhecido apenas por um restrito círculo de aficcionados, acreditamos ser útil apresentar resumidamente as idéias principais deste ensaioº tão lúcido e visionário, se lembrarmos que foi escrito precisamente há cincoenta c dois anos atrás, baseado em duas conferências proferidas pela autora na Arts Society em Newham e na Odtaa em Girton College (duas faculdades para mulheres na Universidade de Cambridge) em outubro de 1928. Na própria Inglaterra, o livro tem sido reeditado, a partir de 1929, em datas cada vez mais próximas, com direitos autorais de Quentin Bell (cunhado de Virginia Woolf) e Angelica Garnett (1928).

No primeiro de uma série de seis capítulos, Virginia Woolf alega que - tendo sido convidada para, falar sobre mulheres e ficção - nunca conseguiria chegar a uma conclușo, pois uma mulher precisa ter dinheiro e um quarto próprio, se quiser escrever ficçáo e isto deixaria insolúvel o tema proposto.

Assumindo a personalidade de um "eu" narrador fictício que conversa com uma Mary Beton ou Seton ou Carmichael imaginária (a autora dialogando consigo mesma?), Virginia Woolf propõe nos contar a estória dos dois dias que precederam sua visita a Newham e Girton. Imaginando-se à beira dé um rio, nos jardins de Oxbridge (nome fictício de uma universidade, que seria uma fusão de Oxford 
e Cambridge), ela é interceptada em seu passeio pelo bedel, horrorizado com o fato de ela, uma mulher, estar andando ali. Aqui estava a relva; lá, o caminho. Apenas os membros e professores da Universidade podiam usar a relva; seu lugar era no pedregulho, é o pensamento que ocorre a ela. Ao chegar à bibiloteca, o acesso igualmente lhe é negado, pois apenas são admitidas à biblioteca as senhoras que estiverem acompanhadas por um mebro da Universidade ou que tiverem uma carta de apresentação. E a narradora comenta ironicamente que, ao chegar à porta da capela, atraída pelo som do órgão, não sentia vontade de entrar, mesmo que tivesse direito, pois quem sabe desta vez iriam exigir seu certificado de batismo, ou uma carta de apresentação do diretor.

Ao observar a congregação saindo e entrando na capela, sua mente divaga pelo passado remoto da construção da universidade. Era uma época de fé, em que até os reis e rainhas e mais tarde os mercadores, derramavam riquezas dentro do pátio da universidade, para doar mais cátedras, mais conferencistas, mais bolsas de estudo ò universidade em que aprenderam seus ofícios.

A conversa que a narradora mantém em seguida com Mary Seton na Universidade de Fernham gira em todo da pobreza que sempre caracterizou o sexo feminino. Mary Seton lhe relata da dificuldade que as mulheres tiveram em reunir trinta mil libras para criar uma faculdade para mulheres em 1860. E ambas se questionam: Que faziam então nossas mães, que não tinham riquezas para nos legar? Empoavam seu nariz? Olhavam vitrines? Exibiam-se ao sol de Monte Carlo? Se a mãe de Mary Seton, sua avó e bisavó tivessem deixado seu dinheiro, como seus pais e avôs, para custear bolsas de estudo para uso do próprio sexo, ambas poderiam ter encarado o futuro sem uma confiança indevida numa vida honrada, abrigada numá profissão liberal. Mas a doação de dinheiro a uma faculdade traria consigo a supressão de famílias, pois enriquecer e ter treze filhos - ninguém agüentaria. Por outro lado, conjetura a narradora, não adiantaria perguntar o que teria acontecido se a Sra. Seton, sua mãe e avó tivessem conseguido enriquecer e doado dinheiro à universidade, porque em primeiro lugar era impossível para elas ganhar dinheiro trabalhando, e, em segundo lugar, se tivesse sido possível, a lei lhes negaria o direito de possuir o dinheiro que ganhassem. E apenas a partir dos últimos quarenta e oito anos que a Sra. Seton tem um tostāo seu. Durante os séculos anteriores, o dinheiro teria sido do marido. Conclui a narradora, que, por uma razão ou outra, nossas mães haviam administrado muitíssimo mal 
seus negócios.

De volta à estalagem, diversas idéias atravessam a mente da narradora: por que a Sra. Seton não tinha dinheiro para legar a elas, qual o efeito da pobreza sobre a mente, o órgão soando na capela, as portas fechadas da biblioteca, e como era desagradável ser trancada para fora, talvez quão pior seria ficar trancada por dentro. Termina o dia pensando na segurança e prosperidade de um sexo e na pobreza, e insegurança do outro e do efeito da tradição e da falta de tradição sobre o pensamento de um escritor.

Se no primeiro capítulo Virginia Woolf nos faz vislumbrar a vida numa universidade essencialmente masculina, como Oxbridge, contrastando a, riqueza desta com a pobreza de uma universidade feminina como Fernham, deixando-nos atônitos diante do fato consuinado do descaso com que a educação da mulher era olhada, e pelo qual ela própria era parcialmente culpada, no segundo capítulo a narradora penetra mais a fundo nas razões desta segregação. Deslocamo-nos da Universidade de Oxbridge para o Museu Britânico, pois a série de perguntas despertadas pela visita a Oxbridge Por que um sexo prosperava e o outro era tão pobre? Qual o cfeito da pobreza sobre a ficção? Quais são as condições necessárias para a criação de obras de arte? - precisava de resposta. E, pergunta-nos Virginia Woolf, se a verdade não é achada nas estantes do Museu Britânico, onde estará ela?

Munida de lápis e papel, confiante, ela penetra no Museu. Seu assombro não tem limites: ao examinar o catálogo, descobre que a mulher é, talvez a animal mais discutido no universo. Como poderia där conta da imensidade de material achado, com listas enormes de títulos de livros sobre mulheres, escritos por homens de todos os tipos? Um fenômeno estranhíssimo e, aparentemente, limitado ao sexo masculino. Consultando em seguida a letra $M$ (men), s narradora descobre aliviada que as mulheres não escreveram livros sobre os homens, pois se ela tivesse de ler primeiro tudo que os homens escreveram sobre as mulheres e vice-versa, levaria mais de duzentos anos para ler tudo.

Escolhe alguns livros arbitrariamente e, por não ter curso universitário, percebe sua dificuldade em pesquisar, em canalizar suas perguntas para responder à sua indagação simples e única: por que os mulheres são pobres? $E$, no meio de anotações sob o título "As mulheres e a pobreza", Virginia Woolf continua indagando da razão pela qual, infelizmente, os homens cultos nunca pensam a mes- 
ma coisa acerca das mulheres, num trecho que mostra clara e ironicamente esta contradição: para Pope, a maioria das mulheres não tem absolutamente caráter; para La Bruyère, as mulheres são extremistas; são melhores ou piores que os homens. Goethe as honreva, Mussolini as desprezava. Decidiu pois que era impossível chegar a uma conclusão, pois havia deixado escapar a verdade por entre os dedos.

Em sua indignação, desenhou o semblante raivoso e feio do Frofessor $X$, engajado em escrever sua monumental obra A Inferioridade Mental, Moral e Física do Sexo Feminino, pois não gostamos de ouvir dizer que somos natuialmente inferiores a um homem in. significante. Passada a indignação, permaneceu a curiosidade em descobrir por que todos os auiores escolhidos falavam da mulher com uma raiva disfarçada e complexa. Percebendo que todos estes livros não tinham valor científico, perguntou-se novamente: por que os homens estavam raivosos? Qual a verdadeira natureza de sua raiva?

Constata mais tarde, pelas manchetes de um jornal, que a Inglaterra está sob o domínio de um patriarcado. Ninguém, em juízo perfeito, poderia deixar de perceber a autoridade do Professor X. E, numa argumentação penetrante e sutil, Virginia Woolf faz ser que, lendo o que ele escrevera sobre as mulheres, ela não pensava no que ele dizia, mas nele próprio, pois um argumentador desapaixonado pensa apenas no argumento, como o leitor. Mas ela estava raivosa porque o professor também o estava. A ela parecia absurdo que um homem com tal poder nas mãos pudesse estar raivoso. Mas, possive!mente, quando o professor insistia enfaticamente na inferioridade das mulheres, ele se preocupava não com esse aspecto, mas com sua própria superioridade, protegida como uma jóia de raro valor. A vida para ambos os sexos era árdua, difícil, exigindo uma coragem e força gigantescas. $E$, mais ainda, autoconfiança. E a maneira mais rápida de gerar esta qualidade imponderável, mas tão valiosa, seria imáginando que os outros são inferiores a nós. Daí a importância enorme para um patriarca, que tem de conquistar e dominar, de sentir que grande parte das pessoas são por natureza inferiores a ele.

Aplicando esta observação à vida real, quando um senhor chamou Rebecca West de feminista notória por ter chamado os homens de "snobs", a narradora conclui que isio não era apenas um grito de vaidade ferida; era um protesto contra alguma infração ao seu poder de acreditar en si mesmo. E Virgínia Wcolf nos dá essa pági- 
na belíssima, que é um brōdo de alerta, penetrante e sagaz, às inulheres em todo o mundo: Durante todos estes séculos, as mulheres serviram de espelhos possuidores do delicioso e mágico poder de refletir a imagem do homem duas vezes seu tamanho natural. Sem este poder, a Terra provavelmente ainda seria selvas e pantanais. As glórias de nossas guerras não seriam conhecidas. Nunca teriam existido super-homens e super-heróis. O Czar e o Kaiser nunca teriam usado ou perdido suas coroas. Quaisquer que sejam seus usos em sociedades civilizadas, os espelhos são necessários a toda ação violenta e heróica. Por isso Napoleão e Mussolini insistiam tão enfaticamente na inferioridade das mulheres, pois se elás não fossem inferiores, eles cessariam de crescer. Isto explica parcialmente por que muitas vezes as mulheres são uma necessidade para os homens. Pois se elas começarem a thes dizer a verdade, a imagem no espelho diminuiria; sua adequação à vida diminuiria. Como é que os homens vão continuar julgando, civilizando, legislando, escrevendo, vestindo-se com apuro e discursando em banquetes, se eles não se puderem ver, no café da manhã e no jantar, pelo menos duas vezes maiores que seu tamanho natural? A visão do espelho é de suprema importância porque ela aumenta a vitalidade, e'a estimula o sistema nervoso. Retirem-na e o homem pode morrer, como o toxicômano privado da cocaína. É sob esta ilusão, conclui a narradora, que a ma:oria das pessoas na rua vão trabalhar, dizendo a si mesmas: eu sou superior à metade das pessoas nes'a sala. E foi esta autoconfiança que teve consequiências tão profundas na vida pública e que levou a observações tão estranhás dentro dos limites da consciência masculina.

Ao pagar a conta do restaurante onde lia o jornal - uma volta à realidade - Virginia Woolf nos conta como herdou de uma tia a pensão vitalícia de quinhentas libras por ano , na mesma ocasião em que foi passada a lei que dava o direito do voto às mulheres. Mos entre o voto e o dinheiro, este the parecia muito mais importante ${ }^{3}$ ao se lembrar dos empregos que arranjara antes: trabalhando em jornais, lendo para senhoras idosas, fazendo flores artificiais, ensinando num jardim de infância - tais eram as principais profissões franqueadas às mulheres antes de 1918. Virginia Woolf não descreve a dureza do trabalho nem a dificuldade de viver com 0 salário ganho, pois o que ela considerava um castigo pior era o veneno do medo e da amargura que tais dias geraram nela. Estar sempre trabalhando como uma escrava em algo que não se queria fazer, mais a noção de que o espírito estava perecendo simultaneamente, tudo isto a corró́a. Mas com dinheiro na bolsa, o medo e 
a amargura se vão. Era realmente notável como uma pensão vitalícia muda nosso temperamento; tinha casa, comida e roupa pelo resto de sua vida. Assim, cessavam simultaneamente o esforço, o trabalho, o ódio e a amargura. Como ela diz, eu não precisava odiar nenhum homem; ele não poderia me magoar. Eu não precisava lisonjear nenhum homem; e'e não tinha nada a me dar. Desta maneirá, imperceptivelmente, a narradora começa a, adotar uma nova atitude em relação à outra metade da raça humana, percebendo que era absurdo culpar qualquer classe ou sexo, como um todo. As massas nunca são responsáveis pelo que fazem, levadas por instintos incontroláveis. Também os patriarcas e professores tiveram enormes dificuldades a vencer. Sua instrução talvez tivesse sido tão cheia de erros quanto a dela própria e, dominados pelo instinto de posse e pelo frenesi da aquisição, os homens são levados perpetuamente a desejar os bens e propriedades dos outros, a fazer fronteiras e bandeiras, navios de guerra e gases venenosos, a oferecer suas próprias vidas e a de seus filhos.

A caminho de casa a narradora percebe, ao ver o pintor, a babá, o carregador de carvão e a verdureira trabalhando, quão difícil era agora, em relação ao século passado, distinguir qual destas frofissões era a mais categorizada, a mais útil. Ninguém poderia responder a esta pergunta. Da mesma forma, havia sido tolice de sua parte pedir ao professor provas indiscutiveis da sua argumentação sobre as mulheres, pois os valores atribuidos às diversas aptidões mudam e provavelmente terão mudado completamente em im século. E Woolf anuncia, dentro do mesmo pensamento: além d.sso, dentro de cem anos as mulheres teräo deixado de ser o sexo fraco. Conseqüentemente elas tomarão parte em todas as atividades e esforços que thes eram negados ałé agora. Todas as pressuposições baseadas nos fatos observados quando as mulheres eram o sexo fraco terão desaparecido. Pois tudo pode acontecer quando a condição de mulher cessar de ser uma ocupação protegida.

O capítulo III nos abre uma nova perspectiva, dentro do escopo da narradora que, desapontada com o fato de não haver trazido nenhum pronunciamento importante ou fato autêntico quanto à pobreza das mulheres em relação aos homens, resolve pedir ao historiador para descrever as condições sob as quais viviam as mulheres na Inglaterra elizabetana.

E um eterno enigma a razão pela qual nenhuma mulher escreveu uma palavra daquela extraordinária literatura quando, de cada dois homens, um era capaz de compor uma canção ou soneto. E a 
narradora se pergunta: quais eram as condições em que viviam as mulheres? A lịteratura, a obra de ficção não cai no chão como uma pedra, mas é como uma teia de aranha, presa à vida pelos quatro cantos. Quando uma teia é puxada ou arrebentada, lembramo-nos de que estas teias são o trabalho de seres humanos sofredores, presos a coisas materiais, como saúde, dinheiro e as casas em que moram.

Examinando a História da Inglaterra do Professor Trevelyan, novamente a narradora acha referências à maneira como eram tratadas as mulheres: surrar as esposas era um direito reconhecido ao homem, praticado sem pejo por ricos e pobres; o casamento não era uma questão de afeição pessoal, mas de avareza da familia, principalmente nas classes fidalgas. Esta descrição é aproximadamente do ano 1470, um pouco após Chaucer. Já na época dos Stuarts, ainda era exceção as mulheres de classe média e superior escolherem seus próprios maridos e, quando este havia sido indicado, ele era soberano e senhor. Mas mesmo assim, as personagens femininas de Shakespeare possuem personalidade e caráter, se considerarmos Cleópatra, Lady Macbeth e Rosalind. E a narradora afirma que Trevelyan está dizendo a verdade, ao afirmar isto. Apesar de rão ser historiadora, ela ainda vai adiante, afirmando que as mulheres sempre brilharam em todas as obras de dramaturgos, poetas e romancistas: realmente, se a mulher não tivesse existência a não ser na ficção escrita pelos homens, poder-se-ia imaginá-la uma pessoa da maior importância; muito diversificada; heróica e mesquinha; esplêndida e sórdida; infinitamente bela e feia ao extremo: tão grande quanto o homem, e até mesmo maior. Mas esta é a mulher na literatura; na realidade, como afirma o Professor Trevelyan, ela era trancada, surrada e empurrada de um canto ao outro.

Este estranho monstro, criado pelos historiadores e poetas, não existe, pois para dar vida a esta mulher era preciso pensar poética e prosaicamente ao mesmo tempo. Entretanto, quando se experimenta este método com a mulher elizabetana, somos detidos pela escassez dos fatos: Trevelyan menciona ocasionalmente uma determinada mulher - uma rainha ou grande dama. De mane:ra nenhuma poderiam as mulheres da classe média, apenas com sua inteligência e personalidade, ter participado de qualquer um dos grandes movimentos que constituem a visão do passado do historiador. Ela não deixou diários, poucas cartas, nenhuma peça teatral ou poema, pelos quais pudéssemos julgá-la. Queremos informações: com 
quantos anos se casou? Quantos filhos teve? Como era sua casa? Tinha ela um quarto próprio? Ela mesma cozinhava? Teria empregada? Todos estes fatos provavelmente estão nos registros de paróquia e em livros de conta corrente; a vida da mulher elizabetana típica deve estar espalhada em algum lugar, caso alguém pudesse juntá-la e fazer um livro.

Examinando novamente as estantes, a narradora deplora que não se saiba nada sobre as mu'heres antes do século XVIII: Aqui estou, perguntando por que razão as mulheres não escreviam poesia na época elizabetana, quando eu nem sei como recebiam instrução; se aprenderam a escrever; se tinham seus quartos próprios; quantas mulheres tinham filhos antes dos vinte e um anos; enfim, o que faziam das oito da manhã às oito da noite. Sem dinheiro, casadas quer quisessem quer não aos quinze ou dezesseis anos, teria sido muito estranho se uma delas tivesse subitamente escrito as obras de Shakespeare, conclui a narradora. E isto a faz lembrar de um bispo que declarou ser impossivel a qualquer mulher no passado, presente ou futuro, ter o gênio de Shakespeare. O bispo, complementa Virginia Woolf, pe'o menos estava certo nisso: que teria sido impossível para qualquer mulher ter escrito as obras de Shakespeare na época de Shakespeare.

Woolf compara então a carreira de Shakespeare com a de uma suposta, irmã do mesmo, também extraordinariamente prendada, mas que não foi à escola, não teve a oportun:dade de aprender gramática, lógica, de ler Horácio e Virgílio; seus pais, abastados, queriam que se casasse com um vizinho. Fugindo de casa para não enfrentar a ira do pai, ela vai a Londres onde quer ser atriz. Riram dela e o gerente da companhia teatral the diz que nenhuma mulher poderia se tornar atriz. Por fim engravidou e se suicidou numa noite de inverno.

Seria essa, aproximadamente, a estória de uma mulher na época de Shakespeare e com o gènio de Shakesueare. Woolf concorda com o bispo, pois um gênio como o de Shakespeare não nasce da classe operária, servil e sem instrução. Não nasceu na Inglaterra cios saxões e bretões. Não nasce hoje em dia entre as classes proletárias. Como poderia então ter nescido entre mulhercs cujo trabaTho começava, de acordo com o Professor Trevelyan, mesmo antes de terem deixado de ser crianças, obrigadas pelos pais, de acordo com a lei e a tradiçăo? Mas a narradora admite que deva ter existido uma espécie de genialidade entre as classes operárias, pois uma vez ou outra, uma Emily Bronte ou um Robert Burns provam sua 
presença. Certamente, nada foi anotado. E Woolf até se aventura a pensar que os numerosos poemas anônimos encontrados, foram escritos por mulheres. Segundo Edward Fitzgerald, foi uma mulher que compôs as baladas e as canções populares, cantando-as para seus filhos, ou entretendo-se enquanto fiava, ou ainda durante as noites de inverno.

$A$ verdade é que qualquer mulher que nascesse com um grande talento no século XVI certamente teria enlouquecido, se suicidado ou passado o fim de seus dias numa, cabana isolada, meio feiticeira, meio mágica, temida e escarnecida. Uma moça altamente dotada que tentasse usar seus dons para a poesia teria encontrado tantos obstáculos que certamente teria perdido a sanidade física e mental. Nenhuma mocinha teria podido forçar sua, entrada num palco londrino sem se violentar, porque a castidade tinha, como ainda tem, uma importância religiosa na vida de uma mulher; a castidade está tão intimamente ligada à mulher que, libertar-se jdela exigiria uma grande coragem. Ter levado uma vida livre em Londres no século XVI significaria para uma poetisa ou dramaturga uma tensão nervosa que chegaria a matá-la. Se sobrevivesse, o que tivesse escrito sairia deformado por uma imaginação mórbida e forçada. Por esta razão não existiram peças teatrais escritas por mulheres, pois suas obras estariam sem assinatura. Como diz Woolf, foi a relíquia do senso de castidade que ditou a anonimidade às mulheres, mesmo tão tardiamente no século XIX. Currer Bell, George Eliot, George Sand, todas vítimas de luta interior como o provam seus escritos, procuraram inutilmente se ocultar usando o nome de um homem. Assim elas prestaram homenagem à convenção, encorajada pelos homens, de que a publicidade nas mulheres é abominável. A anoriimidade corre em suas veias. O desejo de se velarem ainda as domina.

Qual seria então o estado de espírito mais propício para o ato de criação? Woolf descobre que talvez até o século XVIII nada havia sido dito a respeito, nem mesmo pelo próprio artista. Foi só no século XIX que se desenvolveu a autoconsciência, tornando-se habitual entre os homens de letras descrever seus pensamentos em confissões e autobiografias, assim como também, após sua morte, foram escritas suas biografias.

Deduz a narradora, desta enorme literatura moderna de confissão e auto-análise, que escrever uma obra genial é quase sempre uma façanha de prodigiosa dificuldade. Tudo está contra a possibilidade de que a. obra sairá dá mente do escritor em sua inteiri- 
cidade, pelas circunstâncias materiais que trabalham contra ela, e pela indiferença nofória do mundo. Assim, o escritor sofre, princifalmente nos anos criativos de sua juventude, toda espécie de perturbação e desencorajamento. E se alguma coisa consegue surgir apesar de tudo, é um milagre, e, provavelmente, nenhuma obra nasce tão completa e perfeita como foi concebida.

O argumento alcança seu ponto culminante quando, ao examinar as estantes vazias, Woolf comenta que, para as mulheres, estas dificuldades materiais foram infinitamente maiores, não só pelo fato de que estava fora de cogitação elas terem seu quarto próprịo - a não ser que seus pais fossem nobres ou muito ricos - como também por não poderem empreender uma jornada à França, como o fizeram Keats, Tennyson e Carlyle, por exemplo. E as dificuldades não materiais eram ainda muito piores, pois a indiferença do mundo que Keats e Flaubert acharam tão difícil de suportar, no caso da mulher não era indiferença, mas hostịlidade. Chegou certamente a hora em que os efeilos do desencorajamento sobre o pensamento do artista deveriam ser medidos, pois se podemos medir o efeito do leite comum tipo $\mathrm{C}$ e do leite tipo $\mathrm{B}$ sobre dois ratos (o primeiro dos quais ficou pequeno e tímido enquanto o outro ficou grande e atrevido), que tipo de alimento damos às mulheres artistas? Segundo o professor Oscar Browning, da Universidade de Cambridge, examinador das alunas de Girton e Newham, após olhar qualquer pilha de provas (sem levar em consideração as notas que pudesse dar), a melhor mulher era intelectualmente inferior ao pior homem.

Pondera a narradora que tais opiniões, vindas de pessoas importantes, devem ter sido suficientemente temiveis mesmo há cincoenta anos.

Qualquer mocinha poderia ler opiniões semelhantes em jornais, mesmo no século $X I X$, e isso diminuiria sua vitalidade e teria um efeito prejudicial sobre seu trabalho. $E$, mesmo que para uma romancista, a afirmação de que as mulheres não são capazes de fazer nada, não produza mais efeito, a mesma afirmação aindal é eficaz para pintoras e musicistas, pois a compositora hoje em dia se encontra no lugar em que a atriz se encontrava, na época de Shakespeare.

Conclui a narradora: é bastante evidente que, mesmo no século XIX, a mulher não era encorajada a ser artista. Muito pelo contrário, ela era desprezada, esbofeteada, repreendida e exortada. Ela era prejudicada mental e fisicamente pela necessidade de se opo- 
às coisas. Assim entramos novamente no domínio daquele complexo masculino que tanto influenciou o movimento feminista: aquele desejo profundo, não tanto de que ela seja inferior mas de que ele seja superior, o que coloca o homem, onde quer que olhemos, não apenas na vanguarda das artes, mas impedindo o caminho da mulher à poltíica também. E Woolf finaliza este parágrafo afirmando que a história da oposição dos homens à emancipação feminina é mais interessante talvez que a própria história da emancipação.

Para concluir este capítulo, Woolf relembra que estas mesmas opiniōes, divertidas agora, já fizeram nossas avós e bisavós derramar lágrịmas. E muito fácil, para quem está numa universidade e tem seu próprio quarto, dizer que os gênios não deveriam se incomodar como tais opiniões. Infelizmente, são exatamente os homens e mulheres de gênio que mais se incomodam com o que é dito deles. Ela nos lembra Keats e Tennyson e termina dizendo que é da natureza do artista se preocupar excessivamente com o que dizem dele. A literatura está repleta de carcaças de homens que se incomodaram além dos limites racionais com as opiniões dos outros. Esta suscetibilidade é duplamente infeliz ,porque o pensamento do artista, para atingir o esforço prodigioso de libertar completa e inteiramente a obra que está dentro dele, deve ser incandescente, como a mente de Shakespeare, pois se alguém alguma vez conseguiu expressar sua obra inteiramente, este alguém foi Shakespeare.

Após haver comentado sobre o estado de espírito mais propício para o trabalho criativo, Woolf inicia o capítulo IV já concluindo que achar uma mulher nesse estado de espírito no século XVI era obviamente impossível, se nós pensarmos nos túmulos elizabetanos, com todas aquelas crianças ajoelhadas rezando, e nas casas com quartos apinhados e escuros, pois nenhuma mulher poderia ter escrito poesia naquela época. Bem mais tarde, talvez, pudéssemos achar alguma grande dama que, desfrutando de seu relativo conforto e liberdade, publicasse algo em seu próprio nome e assim se arriscasse a ser considerada um monstro. Uma desconhecida Miss Austen ou uma Miss Brontë não teriam achado encorajamento nestó época. Mas também veríamos que esta grande dama teria o pensamento perturbado pelo medo e pelo ódio, e seus poemas atestariam este distúrbio: Lady Winchilsea, por exemplo, nascida em 1661, também nobre e sem filhos, cuja poesia irrompe em indignação contra a situação das mulheres. Para ela, os homens são a faç̧ão da oposição, odiados e temidos, porque têm o poder de impedíla de fazer o que quer - escrever. Mas Woolf reconhece que, vez ou 
outra, quando liberta do ódio, do medo e da amargura, a chama dos deuses ardia em Lady Winchilsea. Era uma pena que uma muTher que sabia escrever como ela, tivesse sido forçada ao ódio e à amargura.

Pessando para outra grande senhora, Margaret of Newcastle, a duquesa amada por Lamb e contemporânea de Lady Winchilsea, a narradora comenta que, apesar de diferentes, ambas tinham em comum o fato de serem nobres e sem filhos e de terem o melhor dos maridos. E a mesma explosão de ódio se encontra em seus escritos: as mulheres vivem como morcegos ou corujas, trabalham como animais e morrem como vermes... Woolf lamenta o fato de que Margaret poderia também ter sido poeta, pois sua inteligência vertia em torrentes de rima e prosa, poesia e filosofia, mas congelados em livros que ninguém lê; elà deveria ter aprendido a raciocinar cientificamente, a usar um microscópio e olhar as estrelas, pois, sem instrução, bajulada pelos profssores mas objeto de zombarias na corte, ela se isolou em Welbeck. Que desperdício, uma mulher que chegou a escrever que as mulheres mais bem educadas são aquelas cujos pensamentos são os mais corteses, ter desperdiçado seu tempo rabiscando bobagens e caindo cada vez mais na obscuridade e na loucura, a ponto de as pessoas se apinharem em volta de sua carruagem, quando saía de casa!

A escritora consultada em seguida por Woolf, Dorothy Osborne, escreveu apenas cartas, já que nenhuma mulher sensata e recatada podia escrever livros. A próxima é a Sra. Behn, com a qual a narradora abandona as grandes damas solitárias, que escreviam para seu próprio deleite, e se aproxima da cidade. A Sra. Behn era uma mulher da classe média, cheia de humor, vitalidade e coragem, forçāda a ganhar a vida à custa de sua inteligêneia. O fato de ter de competir com homens e de ter ganho o suficiente para viver, ultrapassa tudo que tenha escrito, pois começa aqui a liberdade da mente, a possibilidade de que, com o passar do tempo, - pensamento estará livre para escrever o que quiser.

Assim, Aphra Behn demonstrou que as mulheres poderiam ganhar dinheiro escrevendo, mesmo com certo sacrificio, e gradualmente, a arte de escrever adquiriu uma certa importância prática. Centenas de mulheres começaram, no decorrer do século XVIII, a aumentar suas mesadas ou a ajudar suas famílias traduzindo ou escrevendo inumeráveis romances de segunda cãtegoria. E a grande atividade mental das mulheres aparente no final do céculo XVIII - escrevendo sobre Shakespeare e traduzindo os clássicos - estava ba- 
seada no fato de que elas podiam ganhar a vida escrevendo. Desta maneira, houve uma mudança no final do século XVIII que foi mais importante do que as Cruzadas ou as Guerras das Rosas: a mulher da classe média começara a escrever. Pois se Pride and Prejudice, Middlemarch, Villette e Wuthering Heights ${ }^{4}$ interessam, então interessa muito mais do que possa ser provado em uma hora de palestra, diz a narradora, que as mulheres em geral, e não mais apenas a aristocrata solitária, trancada em sua casa de campo entre livros e admiradores, passaram a escrever. Sem estas precursoras, Jane Austen e as irmãs Brontë e George Eliot não teria escrito, assim como Shakespeare não teria escrito sem Chaucer, ou Chaucer sem aqueles poetas desconhecidos que prepararam o caminho e dominaram a rudeza da língua. Pois as obras de arte não são partos isolados e solitários, mas são o fruto de muitos anos de pensamentos comuns, do povo como um todo, de modo que a experiência da massa está por detrás da voz isolada. Todas as mulheres deveriam. colocar flores no túmulo de Aphra Behn, pois e!a thes deu o direito de dizer o que pensam e é ela que faz Woolf dizer à sua platéia feminina: ganhem quinhentas libras por ano com vossa inteligência.

Outra indagação vem à narradora, ao chegar ao início do século XIX e encontrar diversas estantes dedicadas inteiramente às obras de mulheres: por que eram quase só romances? $O$ impulso original era para a poesia e tanto na França como na Inglaterra, as pcetisas precederam as romancistas. Além disso, mulheres tão diferentes como Emily Brontë, George Eliot, Charlotte Brontë e Jane Austen foram todas compelidas, por uma força estranha, a escrever romances. Seria pelo fato de terem nascido na classe média e que uma família da classe média, no começo do século XIX, tinha apenas uma sala de estar? Miss Nightingale se queixa de que as mulheres nunca têm meia hora que possam dizer que é sua, pois são sempre interrompidas. Mesmo assim, seria mais fácil escrever em prosá do que poesia ou uma peça teatral, pois não se precisava de tanta concentração. Era esta a maneira de Jane Austen escrever: ela não tinha um quarto próprio e como era constantemente interrompida, na sala de estar, escondia seus manuscritos com um pedaço de mataborrão para que, excetuando sua família, os criados ou visitantes não suspeitassem de sua ocupação. Além disso, todo preparo literário que uma mulher recebia no começo do século XIX era na observação de personagens e na análise de emoções. Evidentemente, quando a mulher da classe média começou a escrever ela naturalmente escreveu romances, se bem que duas das escritoras famosas citadas não eram romancistas por natureza: Emily Brontë de- 
veria ter escrito dramas em verso e George Eliot, história ou biografia. Entretanto, escreveram bons romances. Mas Jane Austen via algo de desonroso em escrever Pride and Prejudice, pois escondia - manuscr:ito quando chegava alguém. Indaga a narradora: será que Pride and Prejudice teria sido um romance melhor, se Jane Austen não julgasse necessário esconder seu manuscrito das visitas? Chega à conclusão que não. E esse é o grande milagre deste romance, pois aqui estava uma mulher, aproximadamente em 1800, escrevendo sem ódio, sem amargura, sem medo, sem protesto, sem sermão. Era assim que Shakespeare escrevia, e quando as pessoas comparam Shakespeare com Jane Austen, provavelmente querem dizer que o pensamento de ambos tinha ultrapassado todos os obstáculos, razão pela qual Austen e Shakespeare impregnam cada palavra que escreveram. Se Jane Austen sofreu de alguma maneira por causa das circunstâncias, foi pela estreiteza de vida imposta, a ela, pois nunca havia atravessado Londres de ônibus, ou almoçado sozinha num restaurante. Por outro lado, talvez fosse de sua própria natureza, não almejar o que não tinha.

Já em relação a Charlotte Brontë, a narradora duvida disso, ao abrir seu romance Jane Eyre, onde surgem frases como: a,creditase que as mulheres sejam muito calmas; mas elas sentem tanto quanto os homens, elas precisam exercitar suas faculdades e precisam de um campo de ação para seus esforços tanto quanto seus irmãos; elas sofrem de uma restrição demasiado rígida, de uma estagnação por demais absoluta, exatamente como os homens iriam sofrer; e é mesquinho por parte de seus próximos mais privilegiados dizer que elas deveriam se limitar a fazer pudins e tricotar meias, tocar piano ou bordar bolsas. E falta de consideração da parte deles condená-las, ou rir delas, se procuram fazer mais ou aprender mais do que a praxe determinou para seu sexo.

De acordo com Woolf, os livros de Charlotte Brontë estão deformados por trechos como este, pois Charlotte Brontë escreve sobre si mesma, em vez de escrever sobre suas personagens, ela escreve indignada, quando deveria escrever com calma, e ela escreve totalmente, quando deveria escrever com sabedoria, pois está em pé de guerra com seu destino. O que teria acontecido se Charlotte Brontë tivesse trezentas libras por ano, tivesse mais conhecimento do mundo, mais experiência, mais relações de amizade? No trecho acima, Brontë aponta exatamente não apenas para seus próprios defeitos como romancista mas para aqueles do sexo feminino de sua época. Ninguém melhor do que ela sabia quanto sels 
gênio teria aproveitado, se não tivesse sido gasto em visões solitárias sobre campos distantes e se lhe tivessem sido concedidos experiência, relacionamentos e viagens. Conclui Woolf que devemos aceitar o fato de que todos aqueles bons romances, Villette, Emma, Wuthering Heights, Middlemarch, foram escritos por mulheres sem mais experiência de vida do que entraria na casa de um respeitável clérigo; escritos naquela sala de estar comum e por mulheres tão pobres que não podiam comprar mais do que algumas folhas de papel de cada vez. Apenas uma delas conseguiu escapar, após muitas vicissitudes, para um casarão escondido, no qual ela se instalou sob c olhar desaprovador do mundo, pois vivia com um homem casado: George Eliot.

Penetrando no problema, da criação da obra literária e no efeito do sexo sobre o escritor, Woolf imagina o romance como uma criação que reflete a vida, como uma estrutura que deixa uma forma em nossas mentes, o que provoca em nós a emoção apropriada. Mas esta forma não é criada pela relação de pedra com pedra, mas pela relação de ser humano com ser humano. Um romance, desta maneira, desperta em nós toda espécie de emoções antagônicas. A vida entra em conflito com algo que não é vida, mas desde que é parcialmente vida, nós o julgamos como vida. A estrutura toda é muito complexa, constituida, de tantos julgamentos e tantas emoções diferentes. Mas os romances se conservam inteiros de modo notável, ocasionalmente, e o que os faz sobreviver é a integridade - a convicção que o romancista nos dá de que esta é a, verdade.

Por outro lado, muitos romances fracassam em algum ponto. Lembrando-se de Jane Eyre e de outros romances, a narradora indaga: o fator sexo iria interferir de algum modo com a integridade de uma romancista? Esta integridade, que ela considera ser a espitha dorsal do escritor? Tomando Jane Eyre como exemplo, Woolf nos mostra como a indignação e a raiva, o medo e a ignorância afetam a imaginação de Charlotte Brontë e a desviam do seu caminho, contraindo seus romances com um espasmo de dor.

Desde que um romance tenha correspondência, com a vida real, seus valores são até certo ponto os da vida real. É óbvio que os valores das mulheres diferem daqueles dos homens. Mas são os valores masculinos que prevalecem. Futebol e esporte são "importantes", comprar roupas e curtir a moda são "fúteis". Estes valores são transferidos para a ficção. Este livro é importante, pensa o crítico, porque trata de guerra. Aquele é insignificante, porque trata de mulheres numa sala de visitas. Toda a estrutura, portanto, do ro- 
mance dos inícios do século XIX foi erguida (se por uma mulher) por uma mente tortuosa, obrigada a alterar sua visão por causa da autoridade externa. E por esta razão havia uma falha no centro do romance de Charlotte Brontë, que o arruirou: ela havia alterado seus valores em deferência à opinião dos outros.

Apenas Jane Austen e Emily Brontë conseguiram escrever como mu:heres, e não como homens. Das milhares de mulheres que escreviam romances naquela época, apenas elas ignoraram completamente as eternas admoestações do eterno pedagogo - escreva isto, pense aquilo. A frase "as romancistas deveriam apenas aspirar à excelência, corajosamente reconhecendo as limitações de seu sexo" foi escrita, diz a narradora, não em agosto de 1828 mas em agosto de 1928 e isso representa para ela a maioria da opinião pública. E, seria necessário uma moça muito resoluta em 1828 para ignorar todas essas descortesias e repreensões e promessas de prêmios. Era freciso ser algo como uma agitadora para dizer a si mesma: Meu Deus, eles não podem comprar também a literatura. A literatura está aberta para todos. Eu não the permito, bedel, me afastar da grama. Trancai vossas bibliokceas, se quiserdes; mas não há barreira, fechadura, ou ferrolho, que possais colocar na liberdade de minha consciência.

Entretanto, qualquer que tivesse sido o efeito do desencorajamento e da, crítica sobre os romances femininos, ambos não tinham importancia se comparados com outra dificuldade que as romancistas do começo do século XIX tinham de enfrentar - não havia tradição por trás delas. Pois nós pensamos através de nossas mães, se somos mulheres. $E$ inútil ir até os grandes escritores para receber ajuda, por mais que os procuremos por deleite. Lamb, Browne, Thackeray, Newman, Sterne, Dickens, De Quincey nunca ajudaram mulher alguma, apesar de elas terem aprendido alguns truques deles e os adaptado. O valor, a progressão do pensamento masculino são diferentes demais do pensamento feminino, para a mulher os plagiar com sucesso. Talvez a primeira coisa que ela achasse, ao começar a escrever, seria a de que não havia uma frase em comum pronta para ser usada. Todos os grandes romancistas escreveram uma prosa natural, rápida, expressiva, matizada, sem cessar de pertencer a todos. Eles a basearam na frase corrente da época. Era uma frase inapropriada para o sexo feminino e tanto Charlotte Brontë como George Eliot não souberam usá-la. Apenas Jane Austen riu dela, e inventou uma frase perfeitamente natural, bem formada, própria para seu uso, e nunca se afastou de!a. Desta maneira, com menos 
talento para escrever do que Charlotte Bronië, ela conseguiu dizer muito mais. Realmente, comenta a narradora, desde que a liberdade e a. plenitude de expressão são a essência da arte, tal falta de tradição, tal escassez e inadequação de instrumentos deve ter infiuído enormemente nas composições literárias femininas. Além disso, um livro não é feito de frases uma após a outra, mas de frases construídas em arcadas e cúpulas. E esta forma também foi construída por homens para satisfazer suas próprias necessidades. Não há razão para pensar que a forma da épica ou do drama poético serve melhor a uma mulher do que a frase. Mas todas as formas mais antigas de literatura já estavam definidas e formadas na ocasião em que ela se tornou escritora. Só o romance era ainda suficientemente jovem para ser moldável em suas mãos. Mas quem poderá dizer mesmo agora, que o romance está moldado corretamente fara seu uso? Quando a mulher tiver adquirido o uso de seus membros, sem dúvida iremos achá-la trabalhando o romance numa forma própria.

As perguntas de como uma mulher iria hoje em dia escrever uma tragédia em verso, a narradora deixa para o futuro. Ela não quer entabular um assunto tão desolador como o futuro da ficção, eia quer apenas chamar nossa atenção para o grande papel que vai ser ciesempenhado no futuro em relação às condições físicas das mulheres. O livro deveria ser adaptado ao corpo e os livros femininos deveriam ser mais curtos e mais concentrados que os dos homens, construídos de tal modo que as mulheres não precisassem de longas horas de trabalho interrupto. Mais uma vez, os nervos dos homens e das mulheres diferem, e para fazê-los trabalhar o melhor possível precisamos achar que tratamento é o melhor para eles quantas horas de trabalho e de descanso. E tudo isto faz parte do assunto mulheres e ficção. Entretanto, onde é que ela - a narradora - irá achar um estudo sobre a psicologia das mulheres, escrito por uma mulher?

No capítulo $V$, Woolf chega finalmente às estantes que contêm livros de autores ainda vivos; homens e mulheres, pois agora há quase tantos livros escritos por mulheres quanto há pelos homens. Ou ,se isto ainda não é bem verdade, pelo menos as mulheres não escrevem apenas romances. Há livros sobre todos os assuntos, assuntos que nenhuma mulher teria ousado abordar, na geração passada. $E$, apesar de predominarem os romances, até estes podem ter mudado, pela associação com livros de outra espécie. E a mulher pode estar começando a usar a escrita como arte e não como meio 
de auto-expressão.

Escolhendo um livro ao acaso, a narradora o considera como o último volume de uma longa série de livros - continuação dos ou. tros que ela já examinara: os poemas de Lady Winchilsea, os escritos de Aphra Behn e os romances das quatro grandes escritoras citadas. Pois se um livro continua o anterior, apesar do nosso costume de julgá-los separadamente, também devemos considerar esta escritora desconhecida como descendente de todas aquelas outras escritoras já mencionadas.

Examinando o primeiro romance de Mary Carmichael, Life's Adventure, a narradora resolve começar pelas frases, lendo-as em voz alta. Percebe que algo não estava em ordem, o suave deslizar de frase após frase estava interrompido. E ela indaga a romancista como se esta estivesse presente: por que razão as frases de Jane Austen não têm a forma certa para você? Será que elas devem ser rejeitadas, pelo fato de Emma e o Sr. Woodhouse estarem mortos ${ }^{5}$ ? Esta concisão, este arquejar podem indicar que a romancista temia algo, talvez ser chamada de sentimental, ou talvez o fato de se lembrar que as produções literárias femininas foram consideradas floridas e então acrescentar alguns espinhos supérfluos. Apesar disso, Woolf aceita o fato de Mary Carmichael romper as frases, como também os parágrafos, pois ela tem todo o direito de fazer isso, se não for por causa da ruptura, mas por causa da criação. E ela só pode ter certeza disso depois de Mary Carmichael se defrontar com uma situação que ela acredite ser verídica. Virando a página, a narradora lê esta frase: Cloé gostava de Olívia. Dirige-se a seu público feminino e pergunta: Não há homens aqui presentes? Vocês garantem que só há mulheres? E acrescenta: Não se sobressaltem. Não enrubeçam. Admitamos na intimidade de nossa própria sociedade que estas coisas às vezes acontecem. As vezes, as muTheres gostam de mulheres.

Que imensa mudança acontecera! Cloé gostava de Olívia talvez pela primeira vez na literatura. Como Antonio e Cleópatra teria sido diferente, mais interessante, se o relacionamento entre Cleópatra e Otávia tivesse sido mais complexo, e não apenas de ciúme por parte de Cleópatra em re!ação a Otávia! Lembrando-se daquela magnífica galeria de personagens femininas, a narradora acha 0 relacionamento delas elementar demais. Pois quase sem exceção, as niulheres são apresentadas na literatura em relacionamento com os homens. Era estranho pensar que todas as grandes heroínas dos romances, até a época de Jane Austen, eram vistas não apenas pelo 
outro sexo mas somente em relação ao outro sexo. E quão diminuta é esta parte na vida de uma mulher, quão pouco pode um homem saber sobre este assunto, observado através de lentes escuras ou rosadas que o sexo coloca em seu nariz! Daí talvez, a natureza peculiar da mulher na literatura, os extremos assombrosos de sua beleza e feiura, suas alternâncias entre bondade celestial e depravação infernal: assim a veria um amante, conforme seu amor aumentasse ou diminuísse, fosse feliz ou infeliz. Já no século XIX isto não acontece, pois as mulheres se tornam mais variadas e complexas. Mesmo assim, parece óbvio que, mesmo nas obras de Proust, os homens são terrivelmente tolhidos e parciais em seu conhecimento das mulheres, como também as mulheres em seu conhecimento dos homens.

Além disso, examinando de novo sua página de leitura, observa Woolf que está ficando evidente que as mulheres, como os homens, têm outros interesses além dos eternos afazeres da vida dorriéstica. "Cloé gostava de Olívia. Elas compartilhavam um laboratório...". Suponham que os homens fossem apenas representados na literatura como amantes de mulheres e nunca como amigos de homens, soldados, filósofos, sonhadores; quão poucos papéis nas peças de Shakespeare lhes seriam atribuídos, como a literatura iria sofrer! Talvez tivéssemos grande parte de Otello e também de Marco Antônio, mas nada de César, nem Brutus, nem Hamlet, nem Lear, nem Jaques - a literatura ficaria incrivelmente empobrecida, como realmente a literatura está empobrecida além do mensurável, pelas portas que foram fechadas às mulheres. Casadas a contragoșto, mantidas num só quarto e numa só ocupação, como poderia um dramaturgo apresentar um relato completo, verdadeiro ou interessante sobre elas? $O$ amor era o único intérprete possível.

Então se Cloé gosta de Olívia e trabalham juntas num laboratório, se Mary Carmichael sabe escrever, se ela tem seu próprio quarto e ganha quinhentas libras por ano, algo de extrema importância aconteceu. Se Mary Carmichael sabe realmente expressar este amor de Cloé por Olívia, ela acenderá uma luz naquele vasto aposento no qual ninguém ainda entrou. E Woolf passa, a observar como Mary Carmichael trabalha, para captar os gestos não registrados, as palavras não ditas ou meio-ditas que se formam quando as mulheres estão sozinhas, sem a iluminação caprichosa e colorida do outro sexo. Para isso ela precisa inventar uma nova combinação de recursos, para absorver o novo no antigo sem perturbar o equilíbrio infinitamente intricado e elaborado do todo. 
E como se poderia justificar o elogio do próprio sexo? Não há maneira de se medir a estatura exata das mulheres. Não há medidas para avaliar as qualidades de uma boa mãe ou a devoção de uma filha, ou a fidelidade de uma irmã ou a capacidade de uma dona de casa. Poucas mulheres, mesmo agora, são formadas em universidades; mal foram testadas pela grande experiência das profissōes. Elas permanecem, mesmo neste ponto, quase sem classificação. Em contraposição, se queremos saber tudo que foi escrito sobre um cidadão desconhecido, é só abrir uma enciclopédia e acharemos todos os detalhes possíveis e imagináveis. Como diz Woolf, somente a providência divina sabe mais a respeito de Sir Harley Butts

Vendo na estante as biografias de Johnson, Goethe, Carlyle, Sterne, Cowper, Shelley, Voltaire, Browning e outros, ela fica pensando em todos esses homens ilustres que, por uma razão ou outra, admiraram, prccuraram, conviveram, amaram, escreveram, confiaram nas mulheres, mostrando o que pode ser descrito apenas como uma necessidade e dependência de pessoas do sexo oposto. E evidente que eles receberam destas relaçõs com as mu!hres algo que seu próprio sexo não podia suprir: um certo estímulo, uma rerovação do poder criativo que apenas o sexo oposto pode dar. Encontrando sua mulher entre os filhos, ou bordando - centro de uma ordem e de um sistema de vida diferentes de seu próprio mundo - este contraste restauraria as faculdades mentais do homem e ele insensivelmente começaria de novo a planejar, a achar a frase ou a cena que estava faltando.

Mesmo sem ser Goethe ou Carlyle, pode-se sentir a natureza deste poder altamente desenvolvido entre as mulheres, diz Woolf. Entra-se num quarto, em qualquer quarto numa rua e toda aquela força extremamente complexa dá feminilidade nos é lançada ao rosto. Pois as mulheres permaneceram dentro de casa durante mithōes de anos, de modo que agora alé as próprias paredes estão permeadas com sua força criativa. Mas esta difere grandemente do poder criativo dos homens. E podemos concluir que seria uma grande lástima se ela fosse impedida ou desperdiçada, pois foi conquistada através de séculos de disciplina férrea e nada há para substituir essa força. Seria uma pena se as mu'heres escrevessem como os homens, ou vivessem como os homens, ou se parecessem com eles, pois se dois sexos já são inadequados, considerando-se a imensidão do mundo, como iríamos dar um jeito com um só sexo? A instrução não deveria salientar e fortalecer as diferenças, 
em vez das similaridades entre os sexos? Quer prazer teria a narradora em observar o Professor $X$ tentando provar ser ele "superior" aos outros tipos de sexos que um explorador espacial descobrisse em outros céus!

Pensando em Mary Carmichael, Woolf teme que ela se transforme em mais uma romancista do tipo naturalista, em vez do tipo contemplativo. Pois mesmo examinando fatos novos - prostitutas, cortesãs - que ultrapassam os limites da respeitável classe méciia, Carmichael ainda estará oprimida por aquela consciência de si mesma em presença do "pecado", herança de nosso barbarismo sexual. Mas $a_{1}$ maioria das mulheres não são prostitutas ou cortesãs. E o que fazem? Com os olhos da imaginação, Woolf vê uma velhinha atravessando a rua com sua filha, ambas respeitavelmente vestidas. Mas se perguntássemos à velha senhora o que esteve fazendo no dia 5 de abril de 1868 ou no dia 2 de novembro de 1875, ela não se lembraria, porque todos os jantares foram preparados, os pratos e xícaras lavados, as crianças enviadas à escola e pelo mundo afora. Nada permanece de tudo isso. Tudo desapareceu. Nenhuma biografia ou história diz uma palavra a respeito. E os romances, sem querer, inevitavelmente mentem.

Dirigindo-se de novo a Mary Carmichael, Woolf diz: todas estas vidas infinitamente obscuras ainda precisam ser escritas. E Mary Carmichael terá de explorar toda essa acumulação de vida não registrada, seja, das mulheres nas esquinas, de vendedoras e velhas nas portas, de moças perambulando. Acima de tudo, Mary Carmichael deverá iluminar sua própria alma e dizer o que a própria beleza ou feiura significam para ela, e qual é sua relação com o mundo da moda feminina, sempre em mutação. A visão de uma loja de modas se prestaria tão bem à caneta do escritor quanto uma montanha nos Andes. E Mary Carmichael também deverá aprender a rir - sem amargura - das vaidades do sexo oposto. Pois quanto as mulheres não aproveitaram dos comentários de Juvenal e da crítica, de Strindberg! Se Mary Carmichael for realmente corajosa e honesta, ela irá por detrás do outro sexo nos contar o que achou; pois um retrato completo do homem nunca será pintado se uma mulher não descrever aquele pontinho escondido atrás de sua orelha.

Em vez de especular o que Mary Carmichael poderia e deveria escrever, a narradora resolve se debruçar mais uma vez sobre - que ela realmente escreveu. Lembrou-se de que Mary Carmichael havia rompido a estrutura frasal de Jane Austen e, ainda mais, a crdem esperada. Talvez inconscientemente, apenas dando às coisas 
sua ordem natural, escrevendo como mulher. Mas o efeito era um tanto surpreendente; não se podia ver uma onda se avolumando, uma crise se aproximando. Portanto, Woolf não podia se congratular Fela profundidade de seus sentimentos, pois cada vez que ela ia sentir as emoções certas nos lugares certos, Mary Carmichael, esta criatura irritante, a afastava, como se o ponto importante estivesse um pouquinho mais adiante. Ela, faz Woolf sentir que, em vez de sermos sérios, profundos e humanos, podemos ser apenas lerdos e convencionais.

Adiante, a narradora percebe outros fatos. Mary Carmichael não era nenhum gênio. Não tinha amor pela, natureza, imaginação poética, humor brilhante ou poder meditativo, como suas grandes predecessoras Lady Winchilsea, Charlotte Brontë, Jane Austen e George Eliot; ela não sabia escrever com a melodia e a dignidade de Dorothy Osborne. Mas, mesmo assim tinha certas vantagens que mulheres de bem maior capacidade não tinham, nem mesmo há cincoenta anos: Os homens não eram mais para ela a facção oposta. Medo e ódio quase que desapareceram. Então não havia dúvida que Mary Carmichael, como romancista, tinha certas vantagens naturais de alta categoria: uma sensibilidade ampla, ansiosa e livre que explorava coisas quase desconhecidas, ainda não escritas, que pousava em detalhes, mostrando que talvez não fossem insignificantes de todo; que trazia à luz do dia coisas enterradas e nos fazia pensar por que haviam sido enterradas. Apesar de desajeitada e sem tradição, Carmichael havia aprendido a primeira grande lição: ela escrevera como mulher, mas como uma mulher inconsciente de seu sexo, de modo que suas páginas estavam repletas daquela curiosa qualidade sexual que só aparece quando o sexo está inconsciente de si mesmo.

Apesar deste aspecto positivo, nenhuma sensação ou percepção ajudariam Mary Carmichael, se ela não conseguisse construir, com elementos transitórios e pessoais, um edifício duradouro, inabalável. Mary Carmichael precisava provar não ser uma escritora superficial. No momento certo, ela começaria a acenar e então surgiriam na memória coisas bem triviais de outros capítulos. E ela faria sentir sua presença, tão naturalmente quanto possível, e nós nos sentiríamos como se tivéssemos chegado ao topo do mundo e o visto estendido à nossa frente.

cos e professores, patriarcas e pedagogos admoestando-a: a senhora

De qualquer modo, Carmichael estava tentando. E a narradora vê novamente diante de si todos aqueles bispos e reitores, médi- 
não pode fazer isso e não vai agir dessa maneira! Não se admitem senhoras sem carta de apresentação! E ela diz a Carmichąel: se você , Farar para praguejar, está perdida. Igualmente, se parar para rir. Pense apenas no salto. Mas havia obstáculos e mais obstáculos. Mesmo assim, Carmichael não se saiu tão mal, levando em consideração que ela não era nenhum gênio, mas uma moça desconhecida escrevendo seu primeiro romance num quarto, sem ter dinheiro nem tempo suficientes. Dêem-lhe mais cem anos, conclui Woolf, dêemThe um quarto próprio e quinhentas libras ao ano, deixem-na falar livremente e retirar a metade do que ela agora escreveu no livro e ela escreverá um romance bem melhor. Ela será poeta.

Capítulo VI: no dia seguinte, após tantas leituras, a narradora foi tentada a olhar pela janela e ver Londres em atividade, nesta manhã de 6 de outubro de 1928. Que fazia a cidade? Parecia estar completamente indiferente às obras de Shakespeare. Ninguém se interessava - e não os culpo, diz Woolf - pelo futuro da ficção, pela morte da poesia ou pelo desenvolvimento de um estilo de prosa feminina que expressasse completamente as idéias das mulheres. Se estas opiniões fossem escritas na calçada, ninguém se inclinaria para lê-las. $E$ a indiferença de pés apressados tê-las-ia apagado em meia hora. Cada passante parecia envolvido em seus afazeres pessoais, todos pareciarr. separados, abbsortos em seus negócios.

Neste instante, há uma pausa completa no tráfego: nada descia a rua, ninguém passava. Uma única, folha se libertou da árvore ro final da rua e caiu, no meio daquela pausa. Era como um sinal caindo, um sinal apontando para aquela força invisível das coisas. A folha parecia apontar para um rio que corria invisivel, dobrando a esquina. Depois ela trouxe, de um lado da rua para o outro, uma, moça e um rapaz, e também um táxi: e os reuniu bem sob minha janela. O casal entrou no táxi e este partiu deslizando, como se levado pela correnteza.

O que era estranho neste clichê era a ordem rítmica com que a imaginação da narradora o investiu; e o fato de que esta visão de duas pessoas entrando num táxi tinha o poder de transmitir algo da própria satisfação de ambos. Pensar - como ela havia pensando nestes dois dias - em um sexo distinto do outro é um esforço, pois interfere com a unidade da mente.

A mente é realmente um órgão muito misterioso, sobre o qual não sabemos nada, apesar de dependermos completamente dele. Por que sinto que há rupturas e oposições na mente, assim como há 
tensões, por causas óbvias, no corpo? O que significa "unidade mental" já que a mente tem um poder tão grande de concentração, que parece não ter um modo de ser único? A mente pode se separar das pessoas na rua, pode pensar espontaneamente com outras pessoas, pode relembrar algo ,através de seus antepassados. Realmente, a mente está sempre alterando seu enfoque, apresentando o mundo em perspectivas diversas. Alguns desses estados mentais parecem ser menos confortáveis que outros. Para continuar neles, inconscientemente escondemos algo e aos poucos, a repressão se torna cansativa. Mas deveria haver um estado de espírito no qual pudéssemos permanecer sem esforço, porque não haveria razão em esconder algo. E esta visão do casal entrando num taxi seria talvez um destes estados de espírito. A mente se sente como se, após ter estado dividida, tivesse se reunido novamente, numa fusão espontânea. Pois a cooperação entre os sexos é natural. Temos um instinto profundo a favor da teoria de que a união do homem com a mulher produz a maior satisfação, a mais completa felicidade. Mas esta satisfação de ver duas pessoas entrando num taxi também nos faz perguntar se haveria dois sexos ná mente correspondendo aos dois sexos no corpo e se ambos também necessitam se unir para obter satisfação e felicidade plenas. A narradora esboça um esquema para o espírito, de modo que em cada um de nós presidam duas forças: uma masculina, outra feminina; que no cérebro masculino o homem predornine sobre a mulher e vice-versa. O estado normal do ser seria aquele em que ambos vivem juntos harmoniosamente, cooperando espiritualmente. Se somos homens, mesmo assim a parte feminina estaria ativa; e uma mulher também deveria ter relaçōes com o homem dentro de si. Talvez Coleridge tivesse querido dizer isso, ao afirmar que uma grande mente é andrógina: é quando esta fusão acontece, em que a mente está totalmente fertilizada e usa todas suas faculciades. Talvez uma mente puramente masculina não possa criar, assim como uma mente totalmente feminina. Woolf resolve examinar mais alguns livros, para testar o que quer dizer um homem com características femininas (man-womanly) e uma mulher com caracteristicas masculinas (woman-manly).

Coleridge, ao afirmar que a mente privilegiada é andrógina, rão queria dizer que é uma mente simpatizante com mulheres. Talvez a mente andrógina esteja menos apta a fazer estas distinçōes do que a mente unissexual. Talvez ela tenha, querido dizer que a mente andrógina é ressoante e porosa, que ela transmite livremente a emoção, criativa, incandescente e íntegra por natureza. De fato, voltamos a Shakespeare como o tipo de mente andrógina. E se é 
verdacie que uma mente evoluida não pensa em sexo separadamente, quão mais difícil é hoje em dia atingir este estado! Chegando aos livros dos escritores contemporâneos, a narradora fica pensando se este fato não estaria na base de algo que já há tempo a desconcertava: nenhuma época fora tão gritantemente cônscia de sexo como a nossa; os inumeráveis livros masculinos sobre as mulheres, no Museu Britânico, provavam isso. Sem dúvida a culpa era da campanha sufragista, que despertou nos homens um desejo imenso de auto-afirmação e que os fez dar mais importância a seu próprio sexo, o que não teria acontecido se não tivessem sido desafiados. Uma vez desafiados, costumamos reagir com excessivo rigor, se nunca o fomos antes. E isto explicaria as características achadas num romance escrito pelo Sr. A. Era muito agradável ler um escritor, após tantas escritoras, pois o romance indicava liberdade mental, pessoal, auto-confiança. Mas, após algumas páginas, uma sombra Forecia atravessar o livro: era uma barra escura e retilínea, parecida com a letra "l" (eu). Woolf começa a desviar, para conseguir enxergar a paisagem por detrás da, letra, mas sempre o "l" a saudava, r, que se tornava cansativo. Não que esse "eu" não fosse respeitável, honesto, lógico, sólido e burilado por séculos de boas escolas c boa a'imentação. Mas o pior é que, na sombra do "eu", tudo esteva sem forma, como num nevoeiro. Aquilo é uma árvore? Não, é uma mulher. Mas... ela não é real, pensa Woolf. Então aparece Allan e sua sombra imediatamente ofuscou Phoebe, pois ele tinha idéias e paixões. A crise pela qual Woolf estava esperando se aproximava e foi apresentada de modo livre, vigoroso, mas também cbsceno. Mesmo assim, ela sentiu-se entendida: parcialmente, por causa da dominância da letra "I", pela aridez que esta lançava à sua volta; e parcialmente por uma razão mais obscura: parecia haver um ubstáculo na mente do Sr. A, que bloqueava seu poder criador. Lembrando-se do almoço em Oxbridge, falando de Tennyson e de Christina Rossetti, parecia a Woolf que o obstáculo estava aí: sem mais murmurar frases românticas, honesto e lógico como o dia, a única coisa que Allan poderia fazer, ao se aproximar de Phoebe, é o que ele realmente faz, sempre de novo, com o virar das páginas. Ciente ca natureza terrível desta confissão, isto tornou-se maçante para Woolf. A "obscenidade" de Shakespeare não é maçante, porque vem do prazer, ao passo que a do Sr. A é proposital: ele está protestando contra a igualdade do outro sexo, ao afirmar sua própria superioridade. Sem dúvida, a literatura, elizabetana teria sido muito ciferente se o movimento feminista tivesse começado no século $X V I$ e não no século XIX. 
Se esta teoria das duas partes da mente for verdadeira, tudo leva a crer que a virilidade se tornou consciente de si mesma os homens estão escrevendo agora apenas com o lado masculino do cérebro. E é um erro uma mulher lê-los, pois ela vai procurar algo que não existe: falta o poder sugestivo. Examinando os comentários do crítico $B$ sobre a arte da poesia, Woolf percebe que seus sentimentos não transmitem mais nada, os sons não se perpetuavam mais um ao outro. As frases do Sr. B caíam no chão - mortas - ao passo que as de Coleridge explodiam e criavam um mundo de idéias. Esta é a única maneira de escrever, da qual se pode dizer que tem o segredo da vida, eterna.

Este fato deplorável significa que - chegando às estantes de Galsworthy e Kipling - algumas das obras-primas dos maiores escritores ingleses contemporâneos não ressoam em nossos ouvidos. Não apenas pelo fato que estes livros celebrem virtudes, reforcem valores e descrevam o mundo masculinos. É que a emoção que permeia estes livros é incompreensível para uma mulher. $O$ fato é que nem Galsworthy nem Kipling têm uma fagulha de mulher dentro de si. Assim, todas suas qualidades parecem cruas e imaturas para uma mulher: falta-thes o poder sugestivo.

Neste estado mental agitado, pondo e tirando livros da estante, a narradora começa a entrever uma época futura de virilidade pura, auto-afirmativa. Não podemos deixar de ficar impressionados em Roma por este sentido de masculinidade imitigável, diz ela. Houve uma reunião de acadêmicos, com a finalidade de desenvolver o romance italiano e até um telegrama foi enviado ao Duce, expressando a esperança de que a era fascista produzisse logo um poeta digno dela. Mas dificilmente um poema pode sair de uma incubadora. A poesia deveria ter uma mãe, tanto quanto um pai. E Woolf teme que o poema fascista seja um terrivel aborto.

Entretanto, se devemos culpar alguém, a culpa recai tanto sobre um quanto sobre o outro sexo. Todos os que criaram um estado de "consciência de sexo" são culpados e são eles que fazem Woolf procurar um livro em épocas passadas, quando o escritor ainda usava ambos os lados de seu cérebro com igualdade. Precisamos voltar a Shakespeare, pois ele era andrógino; assim o foram Keats, Sterne, Cowper, Lamb e Coleridge. Shelley talvez fosse assexuado. Milton e Ben Jonson tinham umas características demasiadamente masculinas. Assim como Wordsworth e Tolstoi. Em nossa época, Proust é completamente andrógino, talvez feminino demais. Mas esta fraqueza é demasiado rara para nos queixarmos, 
já que em certa mistura, o intelecto parece predominar e as outras faculdades mentais enrijecem e se tornam estéreis. Consola-se Woolf com o fato de que esta, fase seja transitória, pois uma grande parte do que ela apresenta agora ao público desta conferência ficará superado e muito do que agora inflama seus olhos se tornará duvidoso para, as futuras gerações.

Mesmo assim, ela daria como primeira frase de sua conferência sobre "Mulheres e Ficção", ser fatal para nós sermos homens ou mulheres; devemos ser uma mulher com características masculinas e vice-versa. Tem de existir no espírito uma certa colaboração entre o homem e a mulher, antes de se concretizar a arte da criação. Um certo casamento de opostos tem de se consumar. A mente em sua totalidade deve estar receptiva, se quisermos sentir que o escritor está comunicando sua experiência numa, plenitude totat. Deve haver liberdade e paz. E o escritor, passada a experiência, deve repousar e deixar seu espírito celebrar as núpclas na escuridão, sem olhar ou questionar o que está acontecendo. E a correnteza do rio leva as lembranças da narradora, como o táxi levou o casal, no enorme fluir do tráfego londrino.

Neste ponto, Mary Beton pára de falar, pois ela nos contou como chegou à prosaica conclusão de que é necessário ganhar quinhentas libras por ano e ter um quarto com chave, se quisermos escrever fiç̧ão ou poesia. Ela tentou desvendar os pensamentos e impressões que a levaram a pensar assim. E nós a seguimos na universidade, pelo Museu Britânico, observando suas fraquezas e falhas e decidindo que efeito tiveram em suas opinióes Nós a contradizemos, diz Woolf, acrescentando nossas próprias deduções. Certo, pois a verdade só se consegue comparando diversos tipos de erro.

Woolf vai concluir agora em seu próprio nome, antecipando duas críticas que, como ela mesma diz, são tão óbvias que não podemos deixar de fazê-las nós mesmos. Primeira: nenhuma opinião foi expressa sobre os méritos comparativos dos sexos, mesmo em se tratando de escritores. Isto foi proposital, porque mesmo que tivesse chegado a ocasião para tal a,valiação, ela não acredita que os dotes espirituais ou de personalidade possam ser pesados, como açúcar ou manteiga, nem mesmo em Cambridge, onde são tantos os peritos em classificar as pessoas. Toda esta contraposição de sexos, qualidades, toda esta reivindicação de superioridade e imputação de inferioridade, pertencem àquela fase da escola primária em que há "lados" e um tem de vencer o outro, para receber 
um prêmio do diretor. As pessoas, ao amadurecerem, param de aureditar em lados, em diretores ou em prêmios. $E$, no que diz respeito a livros, é extremamente difícil rotular, pois as próprias resenhas de literaturá são uma eterna ilustração da dificuldade em julgar. Tanto o elogio quanto a reprovação não significam nada. Medir é a ocupação mais fútil que existe e submeter-se a aferições é a mais servil das atitudes. A única coisa que interessa é escrevermos o que queremos escrever e se isso tem importância eterna ou apenas passageira, não se pode dizer. Sacrificar nossa visão em deferência a um diretor com prêmios ou a um professor com uma régua na mão é uma vil traição.

Em seguida, Woolf acha que podemos objetar que, em tudo isso, ela deu demasiada importância a coisas materiais, como quinhentas libras ao ano, ou uma fechadura na porta, pois o espírito deveria estar acima destas coisas. Mas muitas vezes os grandes poetas foram pobres. E cita então as palavras de Sir Arthur Quiller-Cough (do seu livro The Art of Writing) que sabe me'hor do que ela o que é preciso para um poeta criar: dos grandes poetas dos últimos cem anos, apenas Keats, Browning e Rossetti não estudaram em universidades; destes três, apenas Keats foi pobre. Fode ser brutal, mas a teoria de que o gênio poético sopra onde quer, igualmente para pobres e ricos, não é verdadeira. A verdade É que, por alguma falha em nosso país, o poeta pobre nunca, teve nem terá chance alguma.

$E$ isto mesmo, diz Woolf. A liberdade intelectual depende de coisas materiais. $E$ as mulheres sempre foram pobres, desde o início dos tempos. Nunca tiveram liberdade intelectual e portanto nunCé tiveram oportunidade de escrever poesia. Por esta razão ela enfatiza tanto o dinheiro e um quarto próprio. Entretanto, contiriva, graças aos esforços daquelas desconhecidas mulheres no passado, graças a duas guerras (a da Criméia tirando Florence Nightingale ${ }^{6}$ da sala de visitas e a guerra européia que abriu as portas à mulher da classe média, sessenta anos mais tarde) estes males Estão sendo sanados. Senão, vocês não estariam aqui hoje e a oportunidade de ganhar quinhentas libras ao ano seria ainda remota.

Entretanto, vocês podem objetar, por que dar tanta importância a livros escritos por mulheres, se é preciso tanto esforço e nos pode fazer discutir com amigos? São egoístas as razões de Woolf. Como a maioria das inglesas sem curso universitário, ela adora ler, mas ultimamente a leitura ficou monótona, pois a histó- 
ria trata sempre de guerras a biografia de grandes homens, a poesia se tornou estéril e a respeito da ficção ela não quer dizer mais nada, pois já mostrou sua falta de talento como crítica da literatura moderna. Então Woolf nos pede para escrevermos qualquer tipo de livro, sem hesitar diante de um assunto, por mais trivial ou vasto. De uma maneira ou outra, espera, que tenhamos dinheiro suficiente para viajar ou descansar, para contemplar o futuro ou o passado do mundo, para divagar sobre os livros e penetrar no fundo da correnteza. Ela não quer nos limitar à ficção: se vocês quiserem me agradar, escrevam livros de viagens e de aventuras, pesquisa e erudição, história e biografia, crítica, filosofia e ciência. Deste modo, vocês vão ser úteis à arte da ficção. Pois os livros se influenciam mutuamente. Além disso, considerando qualquer grande figura do passado - Sapho, Lady Murasaki, Emily Brcntë - vamos ver que elas são tanto herdeiras quanto eriadoras e apareceram porque as mulheres se acostumaram a escrever naturalmente.

Olhando suas anotações, Woolf descobre que seus motivos não foram tão egoístas assim, pois através destes comentários corre a conviç̧ão - ou instinto - de que é necessário escrever bons livros e que os bons escritores, mesmo mostrando qualquer tipo cie depravação, ainda são seres humanos e bons. Desta maneira, pedindo a nós para escrever mais livros, Woolf está nos pedindo fazer algo para nosso próprio bem, e para o bem de todos. Ela não sabe como justificar este instinto ou crença. A realidade parece ser algo errática, na qual não podemos confiar - ela é achar da numa estrada poeirenta, numa tira de jornal na rua, numa flor ao so!. As vezes, parece estar em formas longínquas demais para discernirmos sua natureza. Mas o que quer que toque, a realidade fixa e torna eterno. E o escritor tem a oportunidade de viver, em contato com esta realidade, mais do que outras pessoas. E é sua obrigação achá-la, recolhê-la e comunicá-la aos outros. A leitura de Lear, Emma ou La Recherche du Temps Perdu opera uma curiosa transformação nos sentidos; nós vemos mais intensamente, - mundo descoberto parece receber uma, vida mais intensa. Assim, ao nos pedir que ganhemos nosso dinheiro e tenhamos nosso próprio quarto, Woolf está nos pedindo para viver uma vida invigorante, na presença da realidade, consigamos ou não transmitíla.

E como a pressão da convenção nos pede acabar um discurso com uma peroração, Woolf nos implora lembrarmos nossas resconsabilidades, e quanto depende de nós, e da influência que podemos exercer sobre o futuro. Mas, vasculhando sua própria men- 
te, ela näo acha estes sentimentos e se vê dizendo prosaicamente que é muito mais importante sermos nós mesmas que qualquer cutra coisa. Pensem nas coisas por si mesmas em vez de sonhar em influenciar os outros.

Novamente Woolf se lembra de que, quando uma mulher se dirige a outras mulheres, ela deveria ter algo muito desagradável reservado para o fim. As mulheres costumam ser severas com as outras mulheres. Elas não gostam das outras mulheres. Mas a verdade é que Woolf gosta das mulheres, de sua informalidade, de sua plenitude, de sua anonimidade. Adotando um tom mais severo, ela pergunta: será que consegui transmitir a vocês os conselhos e reprovações do mundo? Eu lhes falei das opiniōes vis de Browning, Napoleão e Mussolini, como da opinião do Professor $X$, para quem as mulheres são intelectual, moral e fisicamente inferiores aos homens. Como admoestação final, Woolf nos dá a advertência de John L. Davies (em A Short History of Women): quando não se deseja mais ter filhos, as mulheres não são mais necessárias.

Como nos encorajar a enfrentar a vida? Woolf diria às moças: vocês são terrivelmente ignorantes. Vocês nunca descobriram nada de importante, nunca fizeram tremer um império ou levaram um exército à luta. Vocês não escreveram as obras de Shakespeare. Qual é sua desculpa? Pode-se facilmente dizer que vocês esta. vam ocupadas, pois sem o trabalho das mulheres, estes mares não teriam sido navegados e estas terras férteis seriam um deserto. Nós pusemos no mundo, criamos, lavamos e ensinamos, até os seis ou sete anos, os milhões de seres humanos que vivem atual. mente no mundo e isto tira tempo.

E verdade. Entretanto, Woolf lembra sua platéia de que já existem na Inglaterra duas universidades femininas desde 1866; que, após 1880, uma mulher casada podia ter suas próprias posses; e que em 1919 ela recebeu o direito do voto. E a maioria das profissões estão abertas às mulheres, há quase dez anos. Refletindo sobre estes imensos privilégios, temos de conceder que a desculpa de não termos oportunidade, treinamento, encorajamento, tempo livre e dinheiro, não é mais válida. Devemos continuar tendo filhos, mas não em dúzias, e sim dois ou três.

Assim, com um certo tempo livre e instrução, devemos iniciar um outro estágio de nossa longa, laboriosa e ignorada carreira. A sugestão de Woolf, em contraposição às mil-outras sugestões pos- 
síveis, toma a forma de ficção: para ela, a suposta irmã de Shakespeare, que morreu tão jovem e nunca, chegou a escrever, ainda vive: em vocês e em mim em muitas outras mulheres que não estão aqui hoje à noite, pois estão levando pratos e pondo filhos ra cama. Mas ela vive; porque os grandes poetas não morrem; elas são presenças constantes; eles precisam apenas da oportunidade de caminhar entre nós. Para Woolf esta oportunidade está agora entrando em nosso poder de dar a esta mulher. Acredita que, se vivermos mais um século e tivermos quinhentas libras por ano e um quarto próprio, se tivermos o hábito da liberdade e a coragem de escrever exatamente o que pensamos, se escaparmos um pouco da sala de estar comum e virmos as pessoas não sempre em relação umas às outras, mas em relação à realidade, se nós olharmos além do espírito "maléfico" de Milton, se nós encararmos o fato de que não há braço no qual possamos nos amparar, porque caminhamos sozinhas e que nossa relação é com a realidade e não apenas com o mundo dos homens e das mulheres - então a oportunidade virá e a poetisa morta que foi a irmã de Shakespeare assumirá o corpo que tantas vezes descartou. Recebendo vida das vidas desssas desconhecidas que a precederam, como seu irmão a recebeu antes dela, ela nascerá. Não podemos esperar que ela nasça sem esta preparação, sem este esforço nosso, sem aquela determinação de que, quando ela renascer, vai achar possível viver e escrever sua poesia. Mas, termina Woolf, eu afirmo que ela virá se nós trabalharmos por ela e, trabalhar, mesmo na pobreza e no anonimato, é válido.

Estes seriam, condensados às vezes, os tópicos que Virginia Woolf aborda em A Room of One's Own. São tópicos que, se já a preocupavam em 1928, qual não seria sua satisfação e entusiasmo, cincoenta anos após, pudesse ela ver suas idéias em franca germinação: mulheres em todo o mundo assumindo aqueles papéis que ela propunha - chefes de estado, ministras, cientistas, romancistãs e poetisas, políticas, comerciantes, executivas, esportistas projetando-se em todas as áreas e profissões antes dominadas pelos homens. Sem esquecer seu lar - com menos filhos, como ela sugere, pois fala do feminismo consciente - a mulher é capaz de conciliar as duas carreiras com a ajuda de seu marido - a imagem de um casal num táxi - e assim assumir um papel mais completo, mais consciente e mais participante na sociedade em que vive e contribuir destarte para: um mundo melhor em que a fome, a guerra e a violência possam ceder lugar à fartura, à paz e ao amor. 


\section{NOTAS}

1 WOOLF, Virginia. A Room of One's Own. Harmondsworth, Penguin, $1975,112 \mathrm{p}$.

2 Como nossa intenção é a de divu!gar as idéias de Virginia Woolf mais do que traduzir o ensaio em sua totalidade, tomamos a liberdade de resumir certos trechos que nos pareceram menos significativos no contexto brasileiro, enquanto outros são traduzidos na íntegra e alguns até em negrito, por considerá-los de maior importância.

i De acordo com J.B. Batchelor e.m "Feminism in Virginia Woolf. In: STRAGUE, C., ed. Virginia Woolf. Englewood-Cliffs, PrenticeHall, 1971. p. 169-79). Virginia Woolf recusa-se a aprovar mais diretamente o movimento sufragista pois ela sempre foi exigente e muito sensível ao ridículo e podia-se perceber que, por mais que concordasse em princípio, seria psicologicamente impossivel a ela associar-se e ser identificada pessoal ou profissionalmente com as sufragistas. Mas sente-se que ela devia estar extremamente consciente do que estava acontecendo...

4 Pride and Prejudice (Jane Austen (recusado para publicação em 1797 e finalmente publicado em 1813, já revisado). Middlemarch (George Eliot, (1871-2). Vilette: Charlotte Brontë (1853). Wuthering Heights (Emily Brontë, (1847).

5 Personagens de Jane Austen.

6 Enfermeira inglesa (1820-1910), que melhorou as condições e normas hospitalares e reorganizou os programas de treinamento de enfermeiras.

\section{REFERENCIAS BIBLIOGRAFICAS}

1 BATCHELOR, J.B. Feminism in Virginia Woo'f. In: STRAGUE, C., ed. Virginia Woolf. Englewocd.Cliffs, Prentice Hall, 1971. p. 169-79.

1. WOOLF, Virginia. A Room of One's Own. Harmondsworth, Penguin Books, 1975. $112 \mathrm{pp}$. 


\section{RES U MO :}

Sendo a intenção deste trabalho divulgar as idéias feministas de Virginia Woolf, foi feita uma tradução livre de seu ensaio A Room of One's Own, no qual esta escritora inglesa trata dos seguintes tópicos: o contraste entre a tradição e a riqueza que sempre caracterizaram as universidades masculinas, em relação à falta de tradição e à pobreza das universidades femininas; o patriarcado, pelo qual as mulheres são parcialmente responsáveis; a falta de conhecimento dos escritores em relação às mulheres; a situação da mulher desde a época elizabetana e a sua falta de condições para a criatividade; a grande revolução feminina a partir do século XVIII, quando a mulher da classe média começa a escrever; o problema da criação literária e do efeito do sexo no escritor; o n.ovo enfoque do relacionamento entre mulheres na ficção; $\circ$ androginismo, como o estado mental mais propício à criação artística; a dependência das mulheres de coisas materiais como dinheiro e um quarto próprio, para adquirirem liberdade intelectual.

\section{S U M M A R Y :}

The aim of this article is to disseminate Virginia Woolf's feminist ideas stated in her essay A Room of One's Own, in a free translation into Portuguese. In this essay, the writer deals with the following topics: the contrast between the wealth and tradition wich have always characterized masculine universities in relation to the lack of tradition and wealth of feminine universities; the rule of patriarchy, for which women are partially responsible; the lack of knowledge the writers have, in relation to women; the situation of the woman since the Elizabethan times and her lack of conditions to create; the great feminist revolution that took place in the XVIIIth century, when the middle-class woman started to write; the problem of literary criation and the effect of sex on the writer; the new focus on the relationship among women in fiction; androginism, the most favourable state of mind for artistic creation; the dependence of women on material things like maney and a room of one's own, in order to have liberty of the mind. 